\title{
Development of a methodological tool for internal control to increase the efficiency of use of fixed assets
}

\author{
Alsou Zakirova, ${ }^{1,}$, Evgenia Zaugarova ${ }^{2}$, Guzaliya Klychova $^{1}$, Rashida Sungatullina ${ }^{3}$, and \\ Elena Klinova ${ }^{3}$ \\ ${ }^{1}$ Kazan State Agrarian University, 65, Karl Marx str., 420015, Kazan, Russia \\ ${ }^{2}$ Saint-Petersburg State Economic University, 21, Sadovaya str., 191023, St. Petersburg, Russia \\ ${ }^{3}$ Vyatka State Agrotechnological University, 133, October Avenue, 610017, Kirov, Russia
}

\begin{abstract}
The basis of the material and technical base of the operation of enterprises are fixed assets. Therefore, the effective organization of accounting and internal control of operations with fixed assets is one of the important tasks facing the management of any enterprise. The purpose of the article consists in development of methodical toolkit of internal control for increase in efficiency of use of the fixed assets. For the development of theoretical bases the article develops the conceptual model of internal control of operations with the fixed assets, which is a logically interconnected system including basic elements of internal control such as purpose, objectives, functions, object, subject, tools, sources of information, regulatory framework, evidence collection, execution of audit results and development of recommendations. In order to improve methodological support, the working papers of internal control were developed in the article. The proposed working documents can be used to identify critical areas of accounting with a high level of risk and determine the means of control necessary to conduct control procedures; to assess the organization and functioning of internal control, the effectiveness of employees responsible for the safety of fixed assets; formation of the information base for management decisions; assessment of risks associated with the acquisition and use of fixed assets.
\end{abstract}

\section{Introduction}

The effective functioning of an enterprise in modern conditions, which consists in improving financial and economic indicators, increasing productivity, increasing the volume of products produced, works performed, services rendered, reducing their cost, involves the rational use of fixed assets [1-3].

Fixed assets take part in the production process for a long time, transfer their value to the manufactured products in parts, but at the same time retain their natural form. In this regard, there is a need for their most efficient use [4-6].

\footnotetext{
* Corresponding author: zakirovaar@mail.ru
} 
Under the conditions of rapid scientific and technological progress, constant improvement of technology, creation of new high-performance types of equipment and mechanisms that replace old equipment, the issues concerning the terms of operation of fixed assets are becoming increasingly relevant. This is associated primarily with the need to comply with the principles of rationality in the implementation of capital investments in connection with the acquisition or creation of new objects of fixed assets [7-9].

At the same time there is a need to improve the quality of accounting information about the safety, receipt and disposal of fixed assets, provided to internal (owners, senior executive management) and external (investors, creditors, fiscal authorities) stakeholders [10-12].

One of the most effective tools to reduce the risks of errors in the accounting of facts of economic activity is internal control $[13,14]$.

In the process of internal control of operations with fixed assets it is necessary to perform the following control activities:

- examine the conditions of storage and operation of fixed assets, their composition and structure;

- to confirm the correctness of documentary registration and reflection in the accounting of operations related to receipt and disposal of fixed assets [15];

- check the correctness of depreciation, appraisal and revaluation of fixed assets and the reliability of their reflection in the accounting [16];

- establish the volume of repairs performed on fixed assets and the legality of their reflection in accounting, depending on the method chosen;

- to check the correctness of accounting of rental and leasing operations;

- to analyze the efficiency of the use of fixed assets [17].

\section{Materials and Methods}

Internal control, being an integral part of the management system, provides information necessary for making management decisions aimed at ensuring financial stability and effective functioning of enterprises [18-21].

To develop the theoretical foundations, we propose a conceptual model of internal control of operations with fixed assets developed by us (Fig. 1).

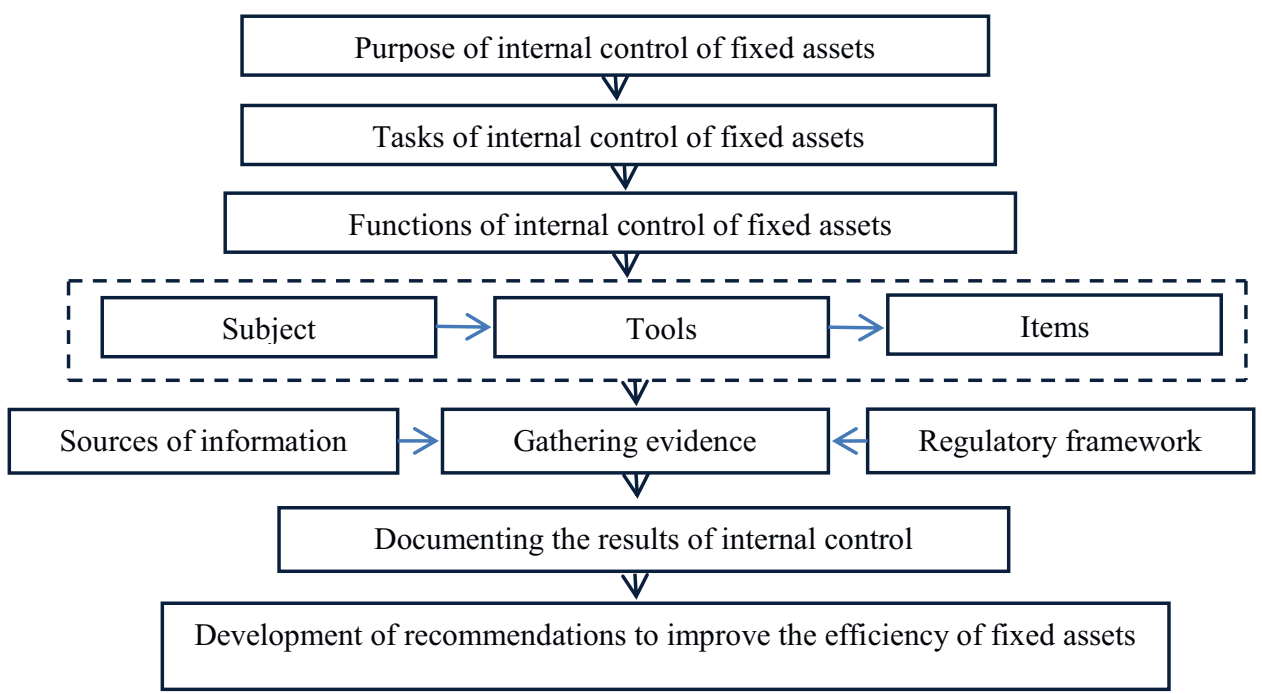

Fig. 1. Conceptual model of internal control fixed assets. 
This model is a logically interrelated system that includes the main elements of internal control, such as purpose, objectives, functions, object, subject, tools, information sources, regulatory framework, evidence collection, execution of inspection results and development of recommendations.

The purpose of internal control of fixed assets is to check the safety, availability and movement of fixed assets, checking the correctness of the organization of accounting operations with fixed assets and their reflection in the financial statements.

To achieve the set goal it is necessary to solve the following tasks:

- check the safety and technical condition of fixed assets;

- to check legality and correctness of documentary registration of operations on movement of fixed assets;

- check the accuracy of calculation of depreciation, how timely and fully included the amount of depreciation deductions in the cost of products manufactured;

- to check the accuracy of recording in the accounts of operations for the movement of fixed assets;

- to establish facts of violation of current legislation at acquisition, use and sale of fixed assets;

- to develop measures to implement the results of control in order to make effective management decisions.

Functions of internal control of fixed assets:

1. All legitimate transactions involving the movement of fixed assets are identified and recorded;

2. Fixed asset transactions are recorded in a timely and detailed manner for reliable classification;

3. The safety of fixed assets shall be monitored;

4. The management system is provided with information that is the basis for making decisions that ensure the normal functioning of the object of control;

5. All available resources of the enterprise are mobilized for effective implementation of production and financial activity of the enterprise and achievement of strategic goals of the enterprise;

6. In the process of internal control deficiencies, embezzlement and abuse are revealed and measures are developed to eliminate and prevent their occurrence in the future.

Subjects of the internal control of operations with fixed assets are:

- owners of the enterprise who carry out control measures independently or with attraction of independent experts;

- employees responsible for the safety and functioning of objects of internal control;

- heads of structural divisions, perform control functions in the process of carrying out their official duties;

- employees of the internal control department whose functional responsibilities are to carry out control activities.

The object of internal control is fixed assets, management decisions and processes associated with their movement.

The main instruments of internal control of fixed assets include documentary and actual control, which provides reliable information to the management of the enterprise for making effective management decisions in the non-current assets management system (Fig. 2). 

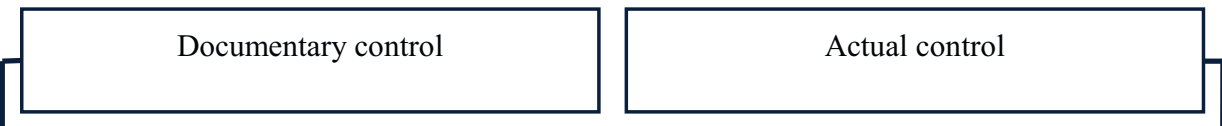

Analytical procedures are used in comparing the availability of fixed assets in different periods, data on their movement report, assessment of relationships between different items and forms of reporting, etc.

Inspection of buildings and facilities involves checking their technical and fire safety condition, ensuring the safety of personnel, uninterrupted production and the safety of manufactured products

Inspection - a method in which the primary accounting documents on the movement of fixed assets are examined on the form of the accounting documents used and the substance of the facts of economic life

Inspection involves checking the performance, completeness, the general technical condition of the operating production equipment technological lines, compliance with the rules of maintenance

Arithmetic check - determines the correctness of calculations and is used to confirm the accuracy of calculations of amounts of accrued depreciation on fixed assets, tax calculations, reporting figures, etc.

Inventory - a method of control, which is used to verify that the actual availability of fixed assets in kind to the accounting data, as well as to find out their safety in the organization

Confirmation - a method of control, through which to obtain information about the objectivity of recording in the accounting records of business transactions and the reality of the balances in the accounts of fixed assets

Oral questioning is used to obtain answers to the Preliminary Stock Assessment questionnaire

Formal verification - reveals defects in the design of documents on accounting for fixed assets, the correctness of the details and the presence of unspecified corrections

Request - a written request to various departments of the enterprise (internal request) and to various businesses and institutions (external request) to provide data on transactions with fixed assets, which are necessary for analysis and comparison.

Tracing is a method used to check the accuracy of data in primary accounting, registers, general ledger, correspondent accounts

Fig. 2. Tools of documentary and actual control of transactions with fixed assets. 
In the process of internal control, actual data is collected from internal and external sources. At the same time analytical and evaluation procedures are carried out, the results of previous inspections are studied [22-25].

The results of control measures are formalized by a report, which accumulates information about the identified material breaches, affecting the formation of financial statements [26-28]. The data in the report is entered from the working documents of internal control, drawn up at various stages of inspection of operations with fixed assets.

Based on the information obtained as a result of internal control, the auditor develops recommendations to improve the use of fixed assets $[29,30]$.

\section{Results}

The basis of the audit is the planning of control measures, which includes the development of an overall strategy, taking into account the industry specifics of the audited economic entity, the establishment of the timing of control procedures, drawing up an internal control program. The internal control program is a detailed list of control areas, regulations, information sources, control period, nature of control procedures (Table 1).

Table 1. Internal control working documents (ICWD) «Internal control program of operations with fixed assets».

\begin{tabular}{|c|c|c|c|c|c|c|}
\hline 总 & 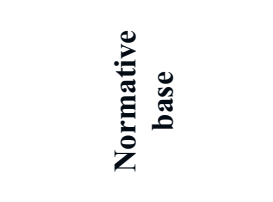 & 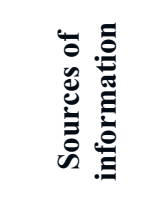 & 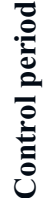 & 这 & 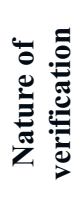 & 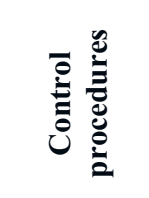 \\
\hline $\begin{array}{l}\text { 1. Evaluation } \\
\text { of the } \\
\text { accounting } \\
\text { system of } \\
\text { fixed assets }\end{array}$ & $\begin{array}{l}\text { Federal Law «On } \\
\text { Accounting». } \\
\text { Accounting } \\
\text { Regulation 6/01 } \\
\text { «Accounting of } \\
\text { Fixed Assets» }\end{array}$ & 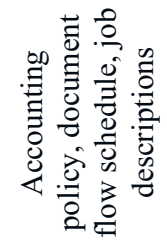 & 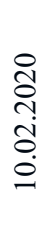 & 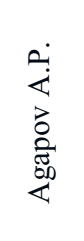 & $\begin{array}{l}\overline{7} \\
\stackrel{\overline{0}}{0}\end{array}$ & 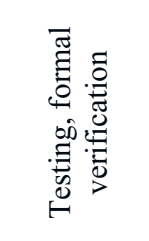 \\
\hline $\begin{array}{c}\text { 2. Checking } \\
\text { the } \\
\text { availability } \\
\text { and safety of } \\
\text { fixed assets }\end{array}$ & $\begin{array}{c}\text { Methodical } \\
\text { instructions on the } \\
\text { inventory of } \\
\text { property and } \\
\text { financial liabilities. } \\
\text { Order of the } \\
\text { Ministry of Finance } \\
\text { of the Russian } \\
\text { Federation of } \\
\text { 13.06.1995 г. № } 49\end{array}$ & $\begin{array}{l}\text { Inventory } \\
\text { cards, } \\
\text { inventory } \\
\text { materials, } \\
\text { contracts of } \\
\text { materially } \\
\text { responsible } \\
\text { persons }\end{array}$ & 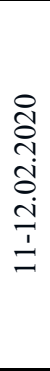 & 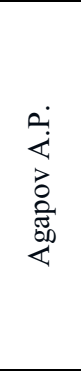 & $\begin{array}{l}\overline{7} \\
\stackrel{0}{0} \\
\mathscr{n}\end{array}$ & 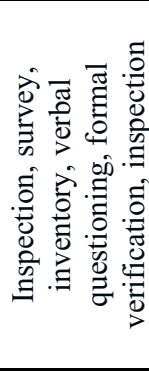 \\
\hline $\begin{array}{l}\text { 3. Checking } \\
\text { the } \\
\text { correctness of } \\
\text { the } \\
\text { documentation } \\
\text { and } \\
\text { accounting of } \\
\text { the receipt of } \\
\text { fixed assets }\end{array}$ & $\begin{array}{c}\text { Accounting } \\
\text { Regulation } 6 / 01 \\
\text { «Accounting for } \\
\text { Fixed Assets»; Plan } \\
\text { of accounts for } \\
\text { financial and } \\
\text { economic activities } \\
\text { of organizations and } \\
\text { instructions for its } \\
\text { application }\end{array}$ & $\begin{array}{l}\text { Contracts, } \\
\text { acts of } \\
\text { acceptance } \\
\text { and transfer } \\
\text { of fixed } \\
\text { assets, } \\
\text { inventory } \\
\text { books, } \\
\text { accounting } \\
\text { registers }\end{array}$ & 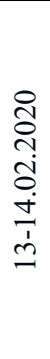 & 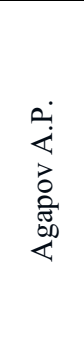 & 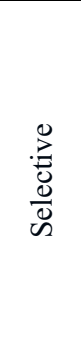 & 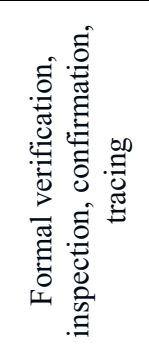 \\
\hline
\end{tabular}




\begin{tabular}{|c|c|c|c|c|c|c|}
\hline $\begin{array}{l}\text { 4. Verification } \\
\text { of the } \\
\text { correctness of } \\
\text { the } \\
\text { documentation } \\
\text { and } \\
\text { accounting } \\
\text { operations of } \\
\text { the disposal of } \\
\text { fixed assets }\end{array}$ & $\begin{array}{c}\text { Accounting } \\
\text { Regulation 6/01 } \\
\text { «Accounting for } \\
\text { Fixed Assets»; Plan } \\
\text { of accounts for } \\
\text { financial and } \\
\text { economic activities } \\
\text { of organizations and } \\
\text { instructions for its } \\
\text { application }\end{array}$ & $\begin{array}{l}\text { Contracts, } \\
\text { acts for the } \\
\text { write-off of } \\
\text { fixed assets, } \\
\text { inventory } \\
\text { books, } \\
\text { accounting } \\
\text { registers }\end{array}$ & 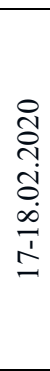 & 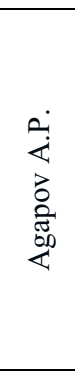 & 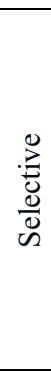 & 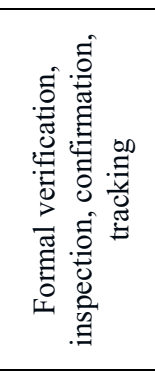 \\
\hline $\begin{array}{l}\text { 5. Checking } \\
\text { the } \\
\text { depreciation } \\
\text { of fixed assets }\end{array}$ & $\begin{array}{l}\text { Accounting } \\
\text { Regulation 6/01 } \\
\text { «Accounting for } \\
\text { Fixed Assets» }\end{array}$ & $\begin{array}{c}\text { Inventory } \\
\text { cards, } \\
\text { statements } \\
\text { of } \\
\text { depreciation }\end{array}$ & 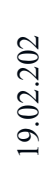 & 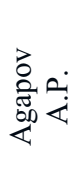 & $\begin{array}{l}0 \\
.0 \\
\frac{0}{0} \\
\text { D }\end{array}$ & 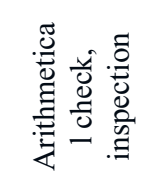 \\
\hline $\begin{array}{l}\text { 6. Checking } \\
\text { the } \\
\text { correctness of } \\
\text { accounting for } \\
\text { the repair of } \\
\text { fixed assets }\end{array}$ & $\begin{array}{c}\text { Accounting } \\
\text { Regulation 6/01 } \\
\text { «Accounting for } \\
\text { Fixed Assets»; Plan } \\
\text { of accounts for } \\
\text { financial and } \\
\text { economic activities } \\
\text { of organizations and } \\
\text { instructions for its } \\
\text { application } \\
\end{array}$ & $\begin{array}{l}\text { Estimates, } \\
\text { certificates } \\
\text { of work } \\
\text { performed, } \\
\text { invoices, } \\
\text { payroll, } \\
\text { accounting } \\
\text { registers }\end{array}$ & 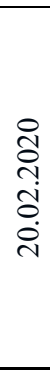 & 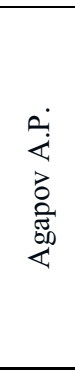 & $\begin{array}{l}\text {.] } \\
\text { on } \\
\text { in }\end{array}$ & 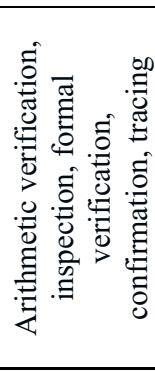 \\
\hline $\begin{array}{l}\text { 7. Checking } \\
\text { the } \\
\text { correctness of } \\
\text { accounting } \\
\text { operations on } \\
\text { the lease of } \\
\text { fixed assets }\end{array}$ & $\begin{array}{c}\text { Accounting } \\
\text { Regulation 6/01 } \\
\text { «Accounting for } \\
\text { Fixed Assets»; Plan } \\
\text { of accounts for } \\
\text { financial and } \\
\text { economic activities } \\
\text { of organizations and } \\
\text { instructions for its } \\
\text { application } \\
\end{array}$ & $\begin{array}{l}\text { Lease } \\
\text { contracts, } \\
\text { acts of } \\
\text { acceptance } \\
\text { of fixed } \\
\text { assets, } \\
\text { accounting } \\
\text { registers }\end{array}$ & 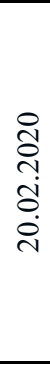 & 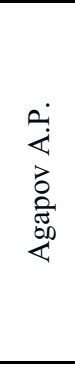 & $\begin{array}{l}\text { :모 } \\
\text { in }\end{array}$ & 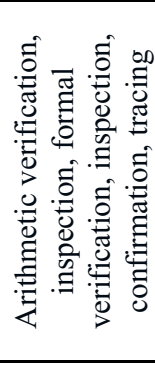 \\
\hline $\begin{array}{l}\text { 8. Analysis of } \\
\text { the use of } \\
\text { fixed assets }\end{array}$ & $\begin{array}{c}\text { Accounting } \\
\text { Regulation 6/01 } \\
\text { «Accounting for } \\
\text { fixed assets» }\end{array}$ & $\begin{array}{l}\text { Synthetic } \\
\text { and } \\
\text { analytical } \\
\text { accounting } \\
\text { registers, } \\
\text { General } \\
\text { ledger, } \\
\text { accounting } \\
\text { (financial) } \\
\text { statements }\end{array}$ & 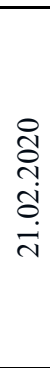 & 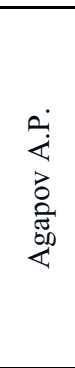 & $\begin{array}{l}\text { 믐 } \\
\text { in }\end{array}$ & 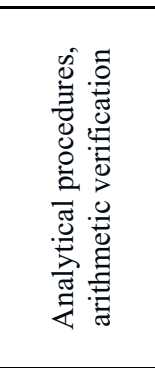 \\
\hline
\end{tabular}

Starting with the accounting (financial) statements for the year 2022, Federal Accounting Standards (FAS) 6/2020 «Fixed Assets» apply.

At the initial stage, the internal controller evaluates the accounting system for fixed asset transactions to obtain information sufficient to plan and determine effective audit approaches. The examination of the accounting system consists in analyzing and evaluating:

- the provisions of the accounting policy regarding the maintenance of fixed asset records;

- information on how responsibilities and authorities are distributed among the employees involved in the accounting of fixed assets transactions; 
- data on organization of document flow, execution and storage of documents, which record the operations with fixed assets movement;

- procedure of fixed assets transactions recording in registers of synthetic and analytical accounting.

To assess the effectiveness of the accounting system it is necessary to use the method of testing on the basis of a specially designed questionnaire (Table 2).

Table 2. ICWD «Assessment test of the accounting system of fixed assets».

\begin{tabular}{|c|c|c|c|c|}
\hline \multirow{2}{*}{ Question content } & \multicolumn{4}{|c|}{ Answer content } \\
\hline & Yes & No & Partially & Note \\
\hline $\begin{array}{l}\text { 1. Are responsibilities and authorities } \\
\text { for preparing primary documents and } \\
\text { maintaining synthetic and analytical } \\
\text { accounting differentiated? }\end{array}$ & + & & & $\begin{array}{l}\text { Job descriptions have been developed } \\
\text { that define the duties and powers of } \\
\text { employees of the accounting service }\end{array}$ \\
\hline $\begin{array}{l}\text { 2. Does the company develop an } \\
\text { accounting policy, including the part } \\
\text { regulating the accounting of fixed } \\
\text { assets? }\end{array}$ & + & & & $\begin{array}{l}\text { An accounting policy has been } \\
\text { developed, which is approved by the } \\
\text { head of the enterprise }\end{array}$ \\
\hline $\begin{array}{l}\text { 3. Are the provisions of the accounting } \\
\text { policy in terms of the methods of } \\
\text { calculating depreciation, the definition } \\
\text { of objects not subject to depreciation, } \\
\text { both for tax and for accounting, the } \\
\text { procedure for revaluation of fixed } \\
\text { assets, the use of a working chart of } \\
\text { accounts, etc.? }\end{array}$ & & & + & $\begin{array}{l}\text { The accounting policy defines the } \\
\text { method of accrual of depreciation of } \\
\text { fixed assets; the procedure for } \\
\text { revaluation of fixed assets. } \\
\text { A working chart of accounts is } \\
\text { developed in the appendix to the } \\
\text { accounting policy. } \\
\text { The accounting policy does not contain } \\
\text { the list of fixed assets that are not } \\
\text { subject to depreciation, both for tax and } \\
\text { accounting purposes }\end{array}$ \\
\hline $\begin{array}{l}\text { 4. Has the accounting department of } \\
\text { the company developed a document } \\
\text { flow schedule? }\end{array}$ & + & & & $\begin{array}{l}\text { The accounting department of the } \\
\text { company has worked out a schedule of } \\
\text { document turnover, which defines the } \\
\text { departments, which a document should } \\
\text { go through and its executors, terms of } \\
\text { its presence in each of the departments. }\end{array}$ \\
\hline $\begin{array}{l}\text { 5. Are the deadlines for documenting } \\
\text { transactions with fixed assets } \\
\text { observed? }\end{array}$ & + & & & $\begin{array}{l}\text { The deadlines for documenting } \\
\text { transactions with fixed assets are } \\
\text { observed }\end{array}$ \\
\hline $\begin{array}{l}\text { 6. Are the principles of timeliness, } \\
\text { completeness and legality of } \\
\text { accounting for the movement of fixed } \\
\text { assets observed? }\end{array}$ & + & & & $\begin{array}{l}\text { Movements of fixed assets are } \\
\text { accounted for in a timely manner, in } \\
\text { full and in accordance with the } \\
\text { regulations. }\end{array}$ \\
\hline $\begin{array}{l}\text { 7. Are the different types of fixed } \\
\text { assets accounted for in separate detail } \\
\text { ledgers? }\end{array}$ & + & & & $\begin{array}{l}\text { Different types of fixed assets are } \\
\text { accounted for in separate detailed } \\
\text { registers }\end{array}$ \\
\hline $\begin{array}{l}\text { 8. Is there a reconciliation of analytical } \\
\text { accounting data for fixed assets with } \\
\text { synthetic accounting data? }\end{array}$ & + & & & $\begin{array}{l}\text { Data of analytical accounting of fixed } \\
\text { assets are reconciled with the data of } \\
\text { synthetic accounting }\end{array}$ \\
\hline $\begin{array}{l}\text { 9. Are the documents reflecting the } \\
\text { receipt and disposal of fixed assets } \\
\text { approved by the head of the enterprise? }\end{array}$ & & & + & $\begin{array}{l}\text { There are documents for the sale of } \\
\text { fixed assets that are not approved by } \\
\text { the head of the enterprise }\end{array}$ \\
\hline $\begin{array}{l}\text { 10. Has the fact of use of leased fixed } \\
\text { assets by the enterprise in its } \\
\text { production activities been established? }\end{array}$ & & + & & $\begin{array}{l}\text { The enterprise does not use leased } \\
\text { fixed assets in production activities }\end{array}$ \\
\hline $\begin{array}{l}\text { 11. Has the fact of leasing fixed assets } \\
\text { and its further reflection in the } \\
\text { accounts been established? }\end{array}$ & + & & & $\begin{array}{l}\text { The company leases out fixed assets. } \\
\text { These transactions are recorded in the } \\
\text { accounting. }\end{array}$ \\
\hline $\begin{array}{l}\text { 12. Does the company carry out a } \\
\text { revaluation of fixed assets and } \\
\text { correctly reflected in the accounting of } \\
\text { its results? }\end{array}$ & & & & $\begin{array}{l}\text { The company is revaluing fixed assets. } \\
\text { These transactions are recorded in the } \\
\text { accounting. }\end{array}$ \\
\hline
\end{tabular}




\begin{tabular}{|l|l|l|l|l|}
\hline $\begin{array}{l}\text { 13. Is the accounting of fixed assets } \\
\text { automated in the accounting } \\
\text { department of the company? }\end{array}$ & + & & & $\begin{array}{l}\text { The program 1C Accounting } 8.3 \text { is } \\
\text { used }\end{array}$ \\
\hline $\begin{array}{l}\text { 14. Are the objects of fixed assets } \\
\text { correctly assigned to depreciation } \\
\text { groups. }\end{array}$ & + & & & $\begin{array}{l}\text { The fixed assets belonging to the } \\
\text { enterprise are correctly assigned to the } \\
\text { corresponding depreciation groups. }\end{array}$ \\
\hline $\begin{array}{l}\text { 15. Is there a systematic analysis of the } \\
\text { correctness of the accrual of taxes? }\end{array}$ & + & & & $\begin{array}{l}\text { The company systematically analyzes } \\
\text { the correctness of the calculation of } \\
\text { taxes }\end{array}$ \\
\hline
\end{tabular}

ICWD «Assessment test of the accounting system of fixed assets» is designed to identify critical areas of accounting with a high level of risk and to determine the controls required for control procedures.

Checking the availability and safety of fixed assets, inspectors find out whether the company is provided with objects of fixed assets, whether individual objects of fixed assets are allocated to business units, whether the current procedure of their accounting is observed, whether there is a commission responsible for the acceptance of fixed assets and registration of its results. Also subject to inspection are agreements on sale and purchase of fixed assets, protocols for determining the contractual prices, the accuracy of determining the original cost in the acts of acceptance and transfer of fixed assets, the correctness of the original cost of fixed assets after their reconstruction, modernization, partial liquidation. To verify the availability and safety of fixed assets we recommend using the «Report on the availability and security of the fixed assets» (Table 3 ).

Table 3. ICWD «Report on availability and preservation of fixed assets».

\begin{tabular}{|c|c|c|c|c|c|c|c|c|}
\hline \multirow[b]{2}{*}{$\begin{array}{c}\text { Name of } \\
\text { the object } \\
\text { of fixed } \\
\text { assets }\end{array}$} & \multirow[b]{2}{*}{ Functional purpose } & \multicolumn{2}{|c|}{$\begin{array}{c}\text { Actual } \\
\text { availability }\end{array}$} & \multirow[b]{2}{*}{ 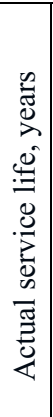 } & \multirow[b]{2}{*}{ 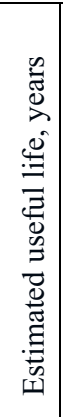 } & \multirow{2}{*}{ 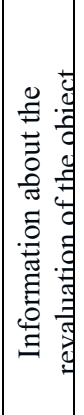 } & \multirow[b]{2}{*}{ 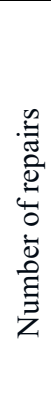 } & \multirow{2}{*}{ 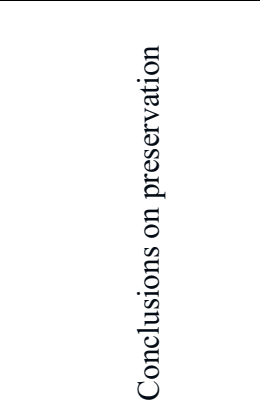 } \\
\hline & & 栉 & 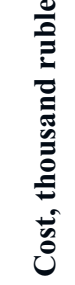 & & & & & \\
\hline $\begin{array}{l}\text { Crawler } \\
\text { bulldozer } \\
\text { based on } \\
\text { the DT- } \\
75 \mathrm{~N} \\
\text { "Kazakhsta } \\
\text { nets" } \\
\text { tractor }\end{array}$ & $\begin{array}{l}\text { Designed for row } \\
\text { sowing of seeds of } \\
\text { grain, small- and } \\
\text { medium-seeded } \\
\text { legumes and seeds of } \\
\text { other crops close to } \\
\text { grain, with the } \\
\text { simultaneous } \\
\text { introduction of } \\
\text { mineral fertilizers }\end{array}$ & 1 & 628 & 3 & 7 & 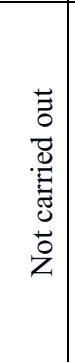 & 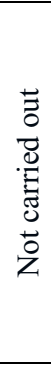 & $\begin{array}{l}\text { A financial liability } \\
\text { agreement has been } \\
\text { concluded. There is } \\
\text { a completed } \\
\text { inventory card. The } \\
\text { room in which the } \\
\text { object is located is } \\
\text { equipped with fire } \\
\text { and burglar alarms }\end{array}$ \\
\hline
\end{tabular}

ICWD «Report on the presence and preservation of fixed assets» contains information on the actual presence, functional purpose, revaluation of the object, the number of repairs, conclusions about the preservation. On the basis of this document, the controller can obtain information to confirm the reality of the accounting items.

When conducting inspections an internal controller establishes the availability of inventory numbers which are assigned to fixed assets at the moment of their acceptance for accounting purposes; determines whether the analytical accounting of fixed assets is 
properly performed by their type; determines the conditions under which fixed assets are used, as well as whether repair works are performed in a timely manner.

Particular attention is paid to checking the inventory of fixed assets, as well as the completeness, timeliness, accuracy of recording its results in the accounting.

To do this, it is necessary to identify enterprise officials who are responsible for the receipt, intra-business movement and disposal of fixed assets, the availability of concluded agreements with them on material responsibility. Then using such a method of control as inspection, determine whether the terms of the fixed assets inventory established in the accounting policy, the order of taking the inventory, the composition of the inventory committee and the procedure for drawing up the results of the inventory measures are observed.

In order to assess the effectiveness of the system of control over the availability and safety of fixed assets we recommend using the following working document (Table 4)

Table 4. ICWD «Test of the effectiveness of the system of control over the availability and safety of the fixed assets».

\begin{tabular}{|l|c|c|l|}
\hline \multicolumn{1}{|c|}{ Contents questions } & \multicolumn{2}{|c|}{ Answers } & \multirow{2}{*}{ Note } \\
\cline { 2 - 3 } & Yes & No & \\
\hline $\begin{array}{l}\text { 1. Are the terms of the inventory of } \\
\text { fixed assets fixed in the accounting } \\
\text { policy of the enterprise? }\end{array}$ & + & & $\begin{array}{l}\text { In the accounting policy of the company } \\
\text { fixed assets inventory dates are fixed }\end{array}$ \\
\hline $\begin{array}{l}\text { 2. Are the terms of the inventory of } \\
\text { fixed assets observed? }\end{array}$ & + & & $\begin{array}{l}\text { The deadlines for conducting an } \\
\text { inventory of fixed assets are observed }\end{array}$ \\
\hline $\begin{array}{l}\text { 3. Are the results of an inventory of } \\
\text { fixed assets reflected in accounting? }\end{array}$ & + & & $\begin{array}{l}\text { The results of the inventory of fixed } \\
\text { assets are recorded in accordance with } \\
\text { the regulations }\end{array}$ \\
\hline $\begin{array}{l}\text { 4. Are persons who are responsible } \\
\text { for the safety of fixed assets at their } \\
\text { places of use appointed and is an } \\
\text { agreement concluded with them on } \\
\text { material responsibility? }\end{array}$ & + & & $\begin{array}{l}\text { An agreement on material responsibility } \\
\text { is concluded with persons responsible } \\
\text { for material responsibility }\end{array}$ \\
\hline $\begin{array}{l}\text { 5. Are fixed assets equipped with } \\
\text { fire and security alarm systems? }\end{array}$ & + & & $\begin{array}{l}\text { Facilities of fixed assets are equipped } \\
\text { with fire and security alarm system }\end{array}$ \\
\hline $\begin{array}{l}\text { 6. Are fixed assets insured against } \\
\text { fires and natural disasters? }\end{array}$ & + & & $\begin{array}{l}\text { Certain items of fixed assets are insured } \\
\text { against fires, natural disasters. Insurance } \\
\text { contracts are checked. }\end{array}$ \\
\hline $\begin{array}{l}\text { 7. Does the enterprise have leased } \\
\text { fixed assets, is there any } \\
\text { reconciliation of settlements with } \\
\text { lessors? }\end{array}$ & & + & $\begin{array}{l}\text { The company has no leased items of } \\
\text { fixed assets }\end{array}$ \\
\hline $\begin{array}{l}\text { 8. Are the primary documents signed } \\
\text { at the enterprise, are the incoming } \\
\text { and outgoing documents that take } \\
\text { into account the fixed assets } \\
\text { registered? }\end{array}$ & + & & $\begin{array}{l}\text { Primary documents are signed, incoming } \\
\text { and outgoing documents are registered, } \\
\text { which take into account the objects of } \\
\text { fixed assets }\end{array}$ \\
\hline $\begin{array}{l}\text { 9. Do accounting employees check } \\
\text { the compliance of the documents } \\
\text { they accept for accounting with the } \\
\text { requirements of current legislation? }\end{array}$ & & + & $\begin{array}{l}\text { Employees of accounting department do } \\
\text { not check compliance of documents } \\
\text { accepted for accounting with } \\
\text { requirements of current legislation }\end{array}$ \\
\hline
\end{tabular}

ICWD «Test to assess the effectiveness of the system of control over the availability and management of fixed assets» allows you to assess the organization and functioning of internal control, the effectiveness of employees responsible for the safety of fixed assets, to establish the availability of methodological support for the conduct of inventories. On the basis of this test, the controller makes conclusions about the effectiveness of internal 
control in order to prevent or detect and correct material misstatements in the financial statements.

In assessing the effectiveness of the system of control over the presence and the items of fixed assets, the internal controller ${ }^{\wedge}$

- $\quad$ analyzes the provisions of the company's accounting policies;

- by comparing the provisions of the accounting policy with the orders for carrying out an inventory, inventory records and acts of inventory results, it is established whether the deadlines for the inventory of fixed assets are being observed;

- to establish the facts of reflection in the accounting of the results of the inventory, it is necessary to check orders, inventory lists, acts of inventory results;

- by conducting a random check of the orders of the head and inventory cards, it is necessary to establish the fact of the appointment of financially responsible persons and the conclusion of agreements on material liability with them;

- by inspection of fixed assets, it is determined whether the fixed assets are equipped with fire and security alarms;

- $\quad$ property insurance contracts are checked by inspection;

- lease agreements for fixed assets are checked by inspection;

- through a formal check, it is checked whether primary documents are endorsed at the enterprise, whether incoming and outgoing documents that take into account fixed assets are registered;

- by oral questioning, the fact of checking the compliance of the documents accepted by them with the requirements of the current legislation is established by the employees of the accounting department.

Internal control over availability and safety of fixed assets implies checking the correctness of accepting an asset for accounting as a fixed asset.

Checking correctness of attribution of assets to fixed assets it is necessary to analyze the accounting policy in the part concerning distinction between fixed assets and labor items. For this purpose it is evaluated the issues of intended use of fixed assets, duration of use, probability of obtaining economic benefits in the future, cost criterion and possibility of operation of fixed assets object within 12 months from the moment of acquisition.

To verify the correctness of the recognition of fixed assets in the accounting, the internal controller with the help of inspection and normative check of primary documents for the presence of all the necessary requisites and signatures establishes their belonging to the economic entity.

Using such methods of control as observation, inquiry, confirmation selectively determined how to use fixed assets in the production and financial activities of the enterprise.

Using the obtained information, the inspector can conclude whether the correctness of classification of fixed assets objects is observed, as it directly affects the methodological basis of accounting and tax accounting, the formation of financial statements.

Internal control of fixed assets operations begins with determining the channels of receipt of fixed assets by the enterprise: purchase for a fee from suppliers, gratuitous receipt, making a contribution to the share capital, buyout of leased fixed assets, construction of a fixed asset.

Depending on the channel of receipt in the accounting business transaction is reflected in certain primary documents confirming the legality of receipt of fixed assets (Fig. 3). 


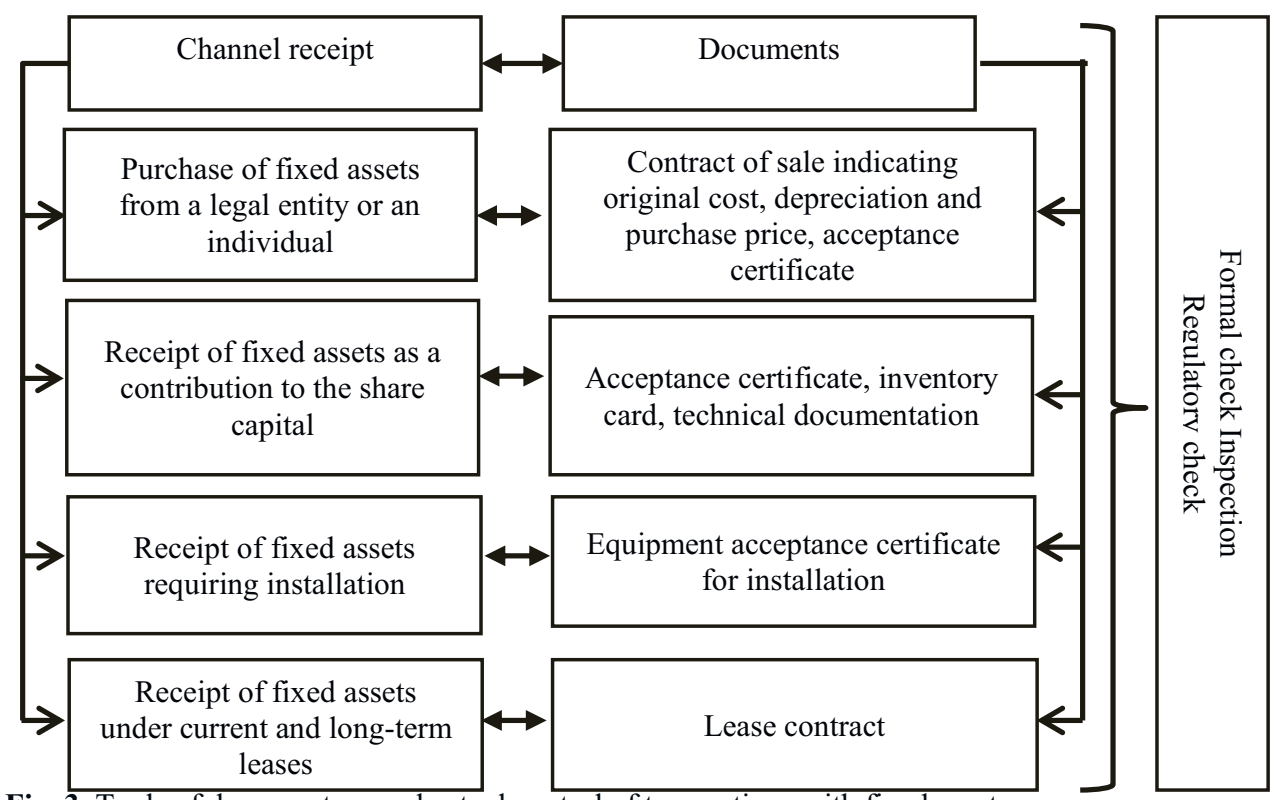

Fig. 3. Tools of documentary and actual control of transactions with fixed assets.

When checking the documentation and accounting for the receipt of fixed assets such internal control procedures are applied as follows:

- obtaining a list of acquired fixed assets, reconciliation of the obtained figures with the debit turnover of the account, which accounts for fixed assets;

- random check of primary documents and physical presence of newly acquired objects;

- determining the value of fixed assets that have been put into operation, their proper reflection in the accounting accounts;

- analysis of compliance with tax law provisions in relation to fixed asset transactions;

- determination of cases of significant receipt of fixed assets and timely write-off of obsolete fixed assets

- formal check of primary documents for availability of all requisites, signatures of responsible persons.

With the internal control of fixed assets, the legality, expediency, and correctness of their receipt in the accounting records are checked. The volume of control procedures carried out during the internal control of the receipt of fixed assets is determined by the inspector independently, depending on his subjective division of operations with fixed assets into atypical and typical, depending on the frequency of these operations, the goals and scale of the company's financial and economic activities, and industry specifics. Atypical operations can be checked in a continuous way, and typical operations can be checked selectively (fig. 4).

During internal control of analytical accounting of fixed assets it is necessary to check inventory numbers, technical documentation, timing of their receipt and crediting, compare these data with the records on the account of fixed assets and information in the inventory cards. In case of detection of discrepancies between the data of synthetic and analytical accounting their reasons, guilty persons and economic consequences are to be found out.

The operations connected with fixed assets retirement are subject to internal control. It is possible to determine the following ways of fixed assets withdrawal such as obsolescence, wear and tear, natural disasters, shortages, theft, reconstruction, sale, gratuitous transfer, on account of contribution to the authorized capital and others. 

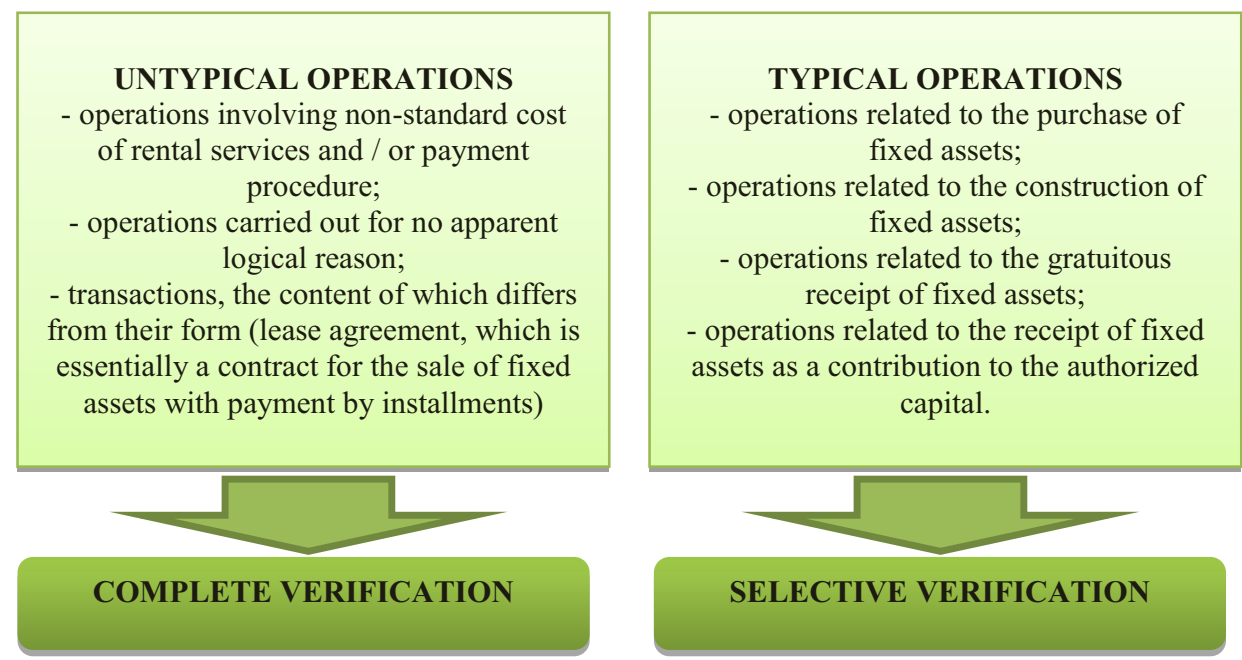

Fig. 4. Methods of checking operations with fixed assets.

The purpose of internal control of operations on retirement of fixed assets is to determine the correctness of the original cost and the amount of accumulated depreciation in full and properly from their accounts, to determine the correctness of the formation of the financial results formed as a result of operations on retirement and recording them on the accounts.

The control procedures performed to achieve the set goal may include:

- obtaining a list of fixed assets that were retired during the reporting period, indicating the original cost and the amount of accumulated depreciation, the reasons for retiring, the sales price, the financial result of operations;

- checking the presence of the head of the company's visa for operations related to the disposal of fixed assets and their documentation;

- verification of each operation for disposal (in case of significant volumes it is allowed a selective verification) and correctness of determination of financial result.

To determine the unsuitability of fixed assets or impossibility and inefficiency of repair work, as well as to issue the necessary documentation on writing-off, the company must create a standing commission by order of the head. Consequently, the internal controller should check the order on creation of the commission on writing off the fixed assets, its composition, the order of writing off the fixed assets and their compliance with the regulations.

Separately, you should check the correctness of recording of material goods received from the dismantling and liquidation of fixed assets.

Documents, which reflect the fact of writing off fixed assets are checked for formal signs of availability of all requisites, a reasoned conclusion of the Commission, signatures of the head of the enterprise and all members of the commission.

To check the correctness of execution of primary documents for the disposal of fixed assets, the ICWD was developed «Checking the execution of primary documents for the disposal of fixed assets» (Table 5) 
Table 5. ICWD « Checking the execution of primary documents for the disposal of fixed assets».

\begin{tabular}{|c|c|c|c|c|c|}
\hline $\begin{array}{c}\text { Primary } \\
\text { document }\end{array}$ & $\begin{array}{c}\text { No and } \\
\text { date of } \\
\text { documen } \\
t\end{array}$ & Control procedure & $\begin{array}{c}\text { Amount } \\
\text { • } \\
\begin{array}{c}\text { Thou.r } \\
\text { ub }\end{array}\end{array}$ & $\begin{array}{l}\text { Identified } \\
\text { violations }\end{array}$ & $\begin{array}{l}\text { Controller's } \\
\text { findings }\end{array}$ \\
\hline $\begin{array}{l}\text { The act of } \\
\text { writing off } \\
\text { fixed } \\
\text { assets }\end{array}$ & $\begin{array}{l}\text { No. } 37 \text { of } \\
\text { Novembe } \\
\text { r } 5.2020\end{array}$ & $\begin{array}{l}\text { Regulatory check } \\
1 \text {. The existence of an order to } \\
\text { write off fixed assets is checked } \\
\text { Formal check } \\
\text { 1. The filling of all details is } \\
\text { checked; } \\
2 \text {. The presence of signatures of } \\
\text { all members of the commission } \\
\text { is checked } \\
\text { Inspection: } \\
\text { 1. The correctness of the } \\
\text { reflection of the materials } \\
\text { remaining from the liquidation } \\
\text { of the object of fixed assets is } \\
\text { checked } \\
2 \text {. The correspondence of } \\
\text { accounts for accounting of } \\
\text { costs associated with } \\
\text { dismantling and writing off of } \\
\text { fixed assets is checked }\end{array}$ & 1542.7 & $\begin{array}{l}\text { Corresponde } \\
\text { nce of } \\
\text { accounts for } \\
\text { accounting } \\
\text { of costs } \\
\text { associated } \\
\text { with } \\
\text { dismantling } \\
\text { and writing } \\
\text { off of fixed } \\
\text { assets is not } \\
\text { indicated }\end{array}$ & $\begin{array}{l}\text { Failure to } \\
\text { recognize costs } \\
\text { leads to a } \\
\text { decrease in other } \\
\text { costs. } \\
\text { It is necessary to } \\
\text { indicate the } \\
\text { correspondence } \\
\text { of accounts for } \\
\text { accounting for } \\
\text { the costs } \\
\text { associated with } \\
\text { the dismantling } \\
\text { and write-off of } \\
\text { fixed assets. }\end{array}$ \\
\hline
\end{tabular}

This document reflects control procedures carried out to verify the primary accounting for compliance with current legislation; it reflects the revealed violations and the controller's recommendations to eliminate them. Checking of primary accounting allows you to establish the reliability of the facts of retirement of fixed assets and ensure the quality of justifying primary documentation. To confirm the correctness of the correspondence of accounts, accounting entries specified in accounting registers are compared with the schemes of correspondence of accounts. An important area of internal control over operations with fixed assets is check of depreciation accrual. To realize control measures one should use testing on the basis of working document of internal control (Table 6).

Table 6. ICWD «Test for checking the correctness of depreciation».

\begin{tabular}{|l|l|l|}
\hline \multicolumn{1}{|c|}{ Questions } & \multicolumn{2}{c|}{ Answer } \\
\cline { 2 - 3 } & Yes & No \\
\hline $\begin{array}{l}\text { 1. Does the current depreciation procedure meet the requirements of the } \\
\text { regulations? }\end{array}$ & & \\
\hline $\begin{array}{l}\text { 2. Does the current procedure of depreciation accrual for fixed assets operating } \\
\text { in an aggressive environment or in a multi-shift mode of operation comply } \\
\text { with the requirements of the regulatory acts? }\end{array}$ & & \\
\hline $\begin{array}{l}\text { 3. Does the current procedure for accruing depreciation on real estate objects } \\
\text { comply with the requirements of regulatory acts? }\end{array}$ & & \\
\hline $\begin{array}{l}\text { 4. Does the current procedure for accrual of depreciation on fixed assets leased } \\
\text { out comply with the requirements of regulatory acts? }\end{array}$ & & \\
\hline $\begin{array}{l}\text { 5. Does the current procedure for calculating depreciation on fixed assets that } \\
\text { are being reconstructed and modernized by the decision of the head of the } \\
\text { organization comply with the requirements of regulatory enactments? }\end{array}$ & & \\
\hline $\begin{array}{l}\text { 6. Does the current procedure for calculating depreciation on fixed assets } \\
\text { transferred to conservation for more than three months by the decision of the } \\
\text { head of the organization comply with the requirements of regulatory } \\
\text { enactments? }\end{array}$ & & \\
\hline $\begin{array}{l}\text { 7. Does the correspondence of accounts for accounting for depreciation of } \\
\text { fixed assets comply with the requirements of regulatory enactments? }\end{array}$ & & \\
\hline
\end{tabular}


Using this document, you can promptly identify violations in the procedure for calculating depreciation. This fact is important, since the amount of accrued depreciation is included in production costs, increasing the cost of products manufactured, work performed and services provided. This, in turn, affects the profit and the formation of the tax base.

To check the correctness of depreciation, a control method such as arithmetic control is used. The internal controller analyzes the accounting policy in terms of accrual methods and their compliance with the provisions of regulatory enactments, their consistent observance from one reporting period to another. In addition, it is determined whether the useful lives of items of property, plant and equipment are correctly established.

In the event of periodic revisions of useful lives, the internal controller should obtain documents confirming such revision by means of arithmetic calculations, analyze how justified the new useful life is and whether depreciation is correctly calculated under the new rates.

Control measures when checking operations for the current and major repairs of fixed assets include:

- comparison of estimated and actual costs for its implementation;

- verification of compliance with the normative time between repairs, timing of repairs, feasibility of calculation of cost estimates;

- verification of the main document formed during the overhaul, the list of defects;

- checking the quality of repair work;

- analysis of the level of repair costs in comparison with their original cost.

During the inspection of leased fixed assets, the internal controller should pay attention to the type and form of lease, which depending on the terms of granting can be current and long-term.

Lease contracts, their availability, correctness of execution of contract terms shall be subject to thorough regulatory inspection. Also subject to control the structure of lease payments and procedure for their calculation, the terms related to the distribution of responsibilities between the parties involved in the maintenance of fixed assets in the condition corresponding to the terms of the contract.

The current lease assumes the transfer of the leased property for a period not exceeding one year. At that, the property shall remain in ownership of the lessor. Accordingly, such objects are listed on the lessor's balance sheet, and the lessee must account for them on an off-balance sheet account. This fact is also checked during internal control.

Long-term lease provides for the transfer of ownership of the leased fixed assets to the lessee at or before the expiry of the lease term in case the lessee has paid the entire contractual price.

Leasing operations, which are a type of investment activity to acquire property and transfer it on the basis of a leasing agreement to individuals or legal entities for a certain fee for a certain period and on certain conditions stipulated by the agreement with the right to redeem the property by the lessee, are subject to special control [31,32].

By means of inspection and arithmetic control, it is checked whether the lease payments for the rented property have been correctly calculated, listed and reflected in the accounting records. The data of accounting registers and lease agreements are subject to study.

The condition for including the costs associated with the operation of the leased property in the cost of production is their documentary confirmation and the use of these facilities for production and management needs.

Internal control of fixed assets ends with an analysis of the effectiveness of their use.

For timely control of the composition and condition of fixed assets, increasing the efficiency of their use and making competent managerial decisions, it is necessary to apply a correctly selected analysis method, which includes the following stages (Fig. 5): 
Information is collected about the objects of fixed assets belonging to the enterprise

The state, dynamics and provision of fixed assets are analyzed

Analytical data are processed and the results obtained are summarized

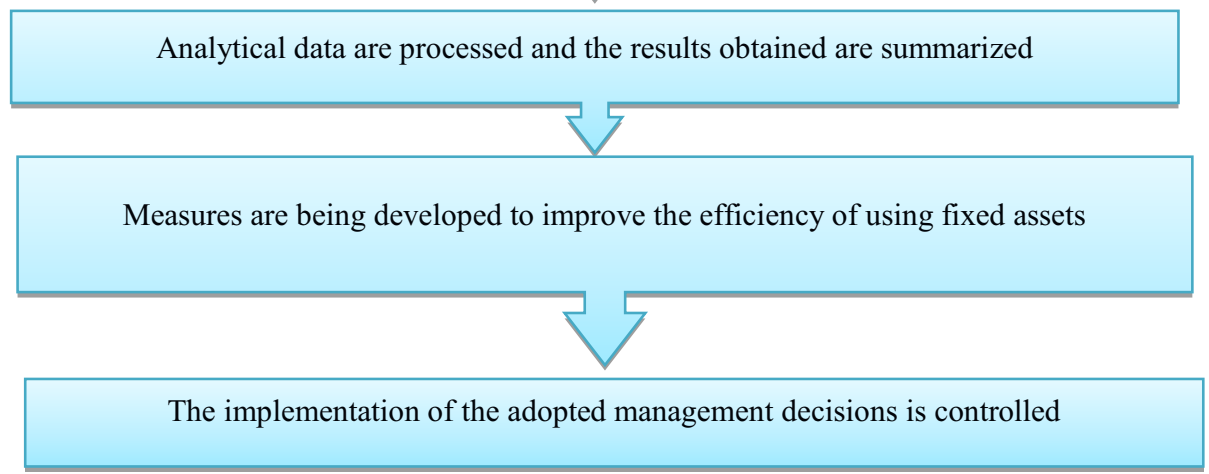

Fig. 5. The main stages of the analysis of fixed assets.

Depending on the areas of analysis, the internal controller performs the following control activities:

1. Analysis of the state of fixed assets:

- the structural composition and movement of the object of fixed assets, the degree of their renewal, retirement and technical condition is studied;

- factors affecting the efficiency of use of fixed assets are studied;

- identifies the degree of influence of intensive and extensive factors, examines the efficiency of fixed assets in terms of capacity and time;

- identifies the impact of fixed assets on the volume of products;

2. Analysis of dynamics of fixed assets - volume, patterns, efficiency of use of investments in non-current assets are studied;

3. Analysis of availability of fixed assets - actual availability of fixed assets is compared to their planned need, which is sufficient for uninterrupted operation of the business. At the same time branch specifics of activity of the company are taken into account.

To characterize the effectiveness of fixed assets, generalized and private indicators are used, which are presented in Table 7.

Table 7. Key indicators characterizing the efficiency of using fixed assets.

\begin{tabular}{|l|l|l|}
\hline \multicolumn{1}{|c|}{ Indicators } & \multicolumn{1}{|c|}{ Calculation Procedure } & \multicolumn{1}{|c|}{ Goneral indicators of concept } \\
\hline Fund productivity & $\begin{array}{l}\text { FPd = Marketable output / } \\
\text { Average annual value of } \\
\text { fixed assets }\end{array}$ & $\begin{array}{l}\text { It characterizes the volume of marketable } \\
\text { output in value terms for each ruble } \\
\text { invested in fixed assets. }\end{array}$ \\
\hline Fund capacity & $\begin{array}{l}\text { FC }=1 / \mathrm{FPd}=\text { Average } \\
\text { annual } \\
\text { cost of fixed assets / Volume } \\
\text { of commercial products }\end{array}$ & $\begin{array}{l}\text { Characterizes the cost of fixed assets } \\
\text { attributable to 1 rub. commercial } \\
\text { products }\end{array}$ \\
\hline Fund profitability & $\begin{array}{l}\text { FPf = Profit / Average annual } \\
\text { value of fixed assets }\end{array}$ & $\begin{array}{l}\text { Characterizes the amount of profit } \\
\text { attributable to the unit of value of the } \\
\text { organization's fixed assets }\end{array}$ \\
\hline
\end{tabular}




\begin{tabular}{|c|c|c|}
\hline Capital-labor ratio & $\begin{array}{l}\mathrm{CL}=\text { Average annual cost } \\
\text { fixed assets of the } \\
\text { organization / average } \\
\text { headcount }\end{array}$ & $\begin{array}{l}\text { Characterizes the level of provision of } \\
\text { employees with fixed assets }\end{array}$ \\
\hline \multicolumn{3}{|c|}{ Particular indicators } \\
\hline $\begin{array}{l}\text { Coefficient of } \\
\text { extensive use of } \\
\text { funds (equipment) }\end{array}$ & $\begin{array}{l}\text { Cext }=\text { Actual working hours } \\
/ \text { Working hours according to } \\
\text { standard }\end{array}$ & $\begin{array}{l}\text { Shows how much useful time the } \\
\text { equipment has worked (the ratio between } \\
\text { the actual working time and the norm) }\end{array}$ \\
\hline Coefficient of Shift & $\begin{array}{l}\text { Cshif }=\text { Number of } \\
\text { production shifts worked / } \\
\text { number of equipment used in } \\
\text { the largest of them }\end{array}$ & $\begin{array}{llll}\begin{array}{l}\text { Characterizes } \\
\text { equipment use }\end{array} & \text { the efficiency of } \\
\end{array}$ \\
\hline $\begin{array}{l}\text { Coefficient } \\
\text { intensity }\end{array}$ & $\begin{array}{l}\text { Cint }=\text { actually produced } \\
\text { volume / planned } \\
\text { (maximum) volume of } \\
\text { products that can be } \\
\text { produced on this equipment. }\end{array}$ & $\begin{array}{l}\text { Gives an indication of the level of } \\
\text { capacity of asset utilization }\end{array}$ \\
\hline Integrity indicators & $\begin{array}{l}\text { Cintegr }=\text { Extensive use of } \\
\text { funds (equipment) coefficient } \\
x \text { Intensity coefficient }\end{array}$ & $\begin{array}{l}\text { Comprehensively determines how } \\
\text { effectively equipment is used in terms of } \\
\text { time and capacity }\end{array}$ \\
\hline
\end{tabular}

At the final stage, the internal controller summarizes the results of the audit, draws conclusions and prepares justified proposals for the management to eliminate the identified deficiencies and use the reserves to improve the efficiency of the enterprise. The revealed violations in accounting of operations with fixed assets are summarized in the working document of internal control (Table 8).

This document summarizes information about the identified violations in certain areas of the audit and recommendations for their elimination, the regulatory framework, sources of information and control procedures used during the audit. ICWD «Identified violations in the accounting of transactions with fixed assets» will allow the internal controller to make an objective report on the results of the audit and form an information base for making management decisions.

Table 8. ICWD «Identified violations in the accounting of transactions with fixed assets».

\begin{tabular}{|c|c|c|c|c|c|c|}
\hline 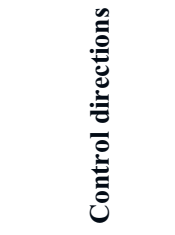 & 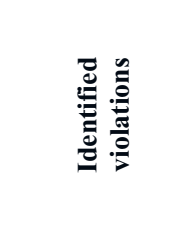 & 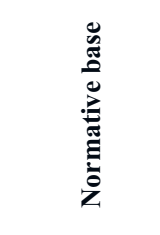 & 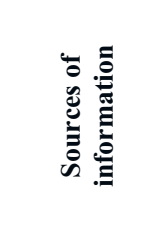 & 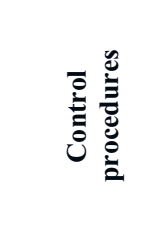 & 㭉葛 & 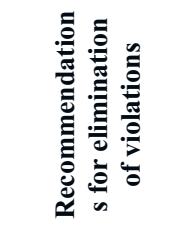 \\
\hline $\begin{array}{l}\text { 1. Checking } \\
\text { the } \\
\text { availability } \\
\text { and safety of } \\
\text { fixed assets }\end{array}$ & $\begin{array}{l}\text { 1) There is no } \\
\text { agreement } \\
\text { with the } \\
\text { person } \\
\text { responsible for } \\
\text { the materially } \\
\text { responsible } \\
\text { person }\end{array}$ & $\begin{array}{l}\text { Labor Code } \\
\text { of the } \\
\text { Russian } \\
\text { Federation }\end{array}$ & $\begin{array}{l}\text { Material } \\
\text { liability } \\
\text { agreement }\end{array}$ & $\begin{array}{l}\text { Normative } \\
\text { verification }\end{array}$ & - & $\begin{array}{l}\text { Recommenda } \\
\text { tions for the } \\
\text { execution of a } \\
\text { liability } \\
\text { agreement }\end{array}$ \\
\hline \multirow{2}{*}{$\begin{array}{l}\text { 2. Checking } \\
\text { the } \\
\text { correctness of } \\
\text { the } \\
\text { documentatio } \\
n \text { and } \\
\text { accounting of } \\
\text { the receipt of }\end{array}$} & $\begin{array}{l}\text { 1) Some } \\
\text { details are } \\
\text { absent in the } \\
\text { act of } \\
\text { acceptance of } \\
\text { fixed assets }\end{array}$ & $\begin{array}{l}\text { Federal Law } \\
\text { «On } \\
\text { Accounting» }\end{array}$ & $\begin{array}{l}\text { Acceptance } \\
\text { and transfer } \\
\text { of fixed } \\
\text { assets }\end{array}$ & $\begin{array}{l}\text { Formal } \\
\text { check }\end{array}$ & - & $\begin{array}{l}\text { Recommenda } \\
\text { tions for } \\
\text { filling in all } \\
\text { requisites }\end{array}$ \\
\hline & $\begin{array}{l}\text { 2) The date of } \\
\text { putting into }\end{array}$ & $\begin{array}{l}\text { Accounting } \\
\text { Regulation }\end{array}$ & $\begin{array}{l}\text { Invoices, act } \\
\text { of }\end{array}$ & Inspection & - & $\begin{array}{l}\text { Recommenda } \\
\text { tions for }\end{array}$ \\
\hline
\end{tabular}




\begin{tabular}{|c|c|c|c|c|c|c|}
\hline fixed assets & $\begin{array}{l}\text { operation of } \\
\text { the object } \\
\text { indicated in } \\
\text { the act does } \\
\text { not coincide } \\
\text { with the date } \\
\text { of acquisition } \\
\text { of the object }\end{array}$ & $\begin{array}{l}6 / 01 \\
\text { «Accounting } \\
\text { for fixed } \\
\text { assets» }\end{array}$ & $\begin{array}{l}\text { acceptance } \\
\text { and transfer } \\
\text { of fixed } \\
\text { assets }\end{array}$ & & & $\begin{array}{l}\text { elimination of } \\
\text { the revealed } \\
\text { discrepancy }\end{array}$ \\
\hline $\begin{array}{l}\text { 3. Checking } \\
\text { the } \\
\text { correctness of } \\
\text { the } \\
\text { documented } \\
\text { registration } \\
\text { and } \\
\text { accounting of } \\
\text { fixed assets } \\
\text { retirement } \\
\text { operations }\end{array}$ & $\begin{array}{l}\text { 1) } \\
\text { Overestimatio } \\
\mathrm{n} \text { of the } \\
\text { residual value } \\
\text { of the sold } \\
\text { object of fixed } \\
\text { assets }\end{array}$ & $\begin{array}{l}\text { Accounting } \\
\text { Regulation } \\
6 / 01 \\
\text { «Accounting } \\
\text { for fixed } \\
\text { assets» }\end{array}$ & $\begin{array}{l}\text { Fixed assets } \\
\text { write-off }\end{array}$ & $\begin{array}{l}\text { Arithmetic } \\
\text { checking, } \\
\text { inspection }\end{array}$ & $\begin{array}{l}31876, \\
9\end{array}$ & $\begin{array}{l}\text { Recommenda } \\
\text { tions for } \\
\text { recalculating } \\
\text { the residual } \\
\text { value of an } \\
\text { item of fixed } \\
\text { assets }\end{array}$ \\
\hline \multirow[t]{2}{*}{$\begin{array}{l}\text { 4. Checking } \\
\text { the } \\
\text { depreciation } \\
\text { of fixed assets }\end{array}$} & $\begin{array}{l}\text { 1) Failure to } \\
\text { comply with } \\
\text { the } \\
\text { requirements } \\
\text { of the } \\
\text { legislation on } \\
\text { the } \\
\text { establishment } \\
\text { of the useful } \\
\text { life of } \\
\text { individual } \\
\text { items of fixed } \\
\text { assets, } \\
\text { depreciation } \\
\text { rates }\end{array}$ & $\begin{array}{l}\text { Accounting } \\
\text { Regulation } \\
6 / 01 \\
\text { "Accounting } \\
\text { for fixed } \\
\text { assets», Tax } \\
\text { Code of the } \\
\text { Russian } \\
\text { Federation, } \\
\text { All-Russian } \\
\text { Classifier of } \\
\text { Fixed Assets }\end{array}$ & $\begin{array}{l}\text { List of } \\
\text { depreciation } \\
\text {, act of } \\
\text { acceptance } \\
\text { and transfer } \\
\text { of fixed } \\
\text { assets }\end{array}$ & $\begin{array}{l}\text { Normative } \\
\text { check, } \\
\text { arithmetic } \\
\text { check }\end{array}$ & - & $\begin{array}{l}\text { Recommenda } \\
\text { tions on the } \\
\text { observance of } \\
\text { the useful life } \\
\text { of individual } \\
\text { items of fixed } \\
\text { assets, } \\
\text { depreciation } \\
\text { rates }\end{array}$ \\
\hline & $\begin{array}{l}\text { 2) Accrual of } \\
\text { depreciation in } \\
\text { the same } \\
\text { month in } \\
\text { which the } \\
\text { object was } \\
\text { taken into } \\
\text { account }\end{array}$ & $\begin{array}{l}\text { Accounting } \\
\text { Regulation } \\
6 / 01 \\
\text { «Accounting } \\
\text { for fixed } \\
\text { assets» }\end{array}$ & $\begin{array}{l}\text { List of } \\
\text { depreciation } \\
\text {, act of } \\
\text { acceptance } \\
\text { and transfer } \\
\text { of fixed } \\
\text { assets }\end{array}$ & $\begin{array}{l}\text { Tracking, } \\
\text { arithmetic } \\
\text { checking }\end{array}$ & 6654 & $\begin{array}{l}\text { Recommenda } \\
\text { tions for } \\
\text { compliance } \\
\text { with the } \\
\text { terms of } \\
\text { depreciation }\end{array}$ \\
\hline $\begin{array}{l}\text { 5. Checking } \\
\text { the } \\
\text { correctness of } \\
\text { accounting } \\
\text { for the repair } \\
\text { of fixed assets }\end{array}$ & $\begin{array}{l}\text { 1) Not all the } \\
\text { costs of } \\
\text { repairing fixed } \\
\text { assets in an } \\
\text { economic way } \\
\text { are included in } \\
\text { the cost of } \\
\text { production }\end{array}$ & $\begin{array}{l}\text { Accounting } \\
\text { Regulation } \\
6 / 01 \\
\text { «Accounting } \\
\text { for fixed } \\
\text { assets»; Plan } \\
\text { of accounts } \\
\text { for financial } \\
\text { and } \\
\text { economic } \\
\text { activities of } \\
\text { organization } \\
\text { s and } \\
\text { instructions } \\
\text { for its } \\
\text { application }\end{array}$ & $\begin{array}{l}\text { Estimates, } \\
\text { acts of } \\
\text { completed } \\
\text { work, } \\
\text { invoices, } \\
\text { payroll, } \\
\text { accounting } \\
\text { registers }\end{array}$ & & 31654 & $\begin{array}{l}\text { Recommenda } \\
\text { tions for the } \\
\text { inclusion of } \\
\text { all costs of } \\
\text { repairing } \\
\text { fixed assets in } \\
\text { an economic } \\
\text { way in the } \\
\text { cost of } \\
\text { production }\end{array}$ \\
\hline
\end{tabular}




\begin{tabular}{|c|c|c|c|c|c|c|}
\hline \multirow[b]{2}{*}{$\begin{array}{l}\text { 6. Checking } \\
\text { the } \\
\text { correctness of } \\
\text { accounting } \\
\text { for lease of } \\
\text { fixed assets }\end{array}$} & $\begin{array}{l}\text { 1) Incorrect } \\
\text { correspondenc } \\
\text { e of accounts }\end{array}$ & $\begin{array}{l}\text { Plan of } \\
\text { accounts for } \\
\text { financial and } \\
\text { economic } \\
\text { activities of } \\
\text { organization } \\
\text { s and } \\
\text { instructions } \\
\text { for its } \\
\text { application }\end{array}$ & $\begin{array}{l}\text { Synthetic } \\
\text { and } \\
\text { analytical } \\
\text { accounting } \\
\text { registers, } \\
\text { General } \\
\text { ledger }\end{array}$ & $\begin{array}{l}\text { Arithmetic } \\
\text { verification, } \\
\text { inspection, } \\
\text { formal } \\
\text { verification, } \\
\text { confirmation } \\
\text {, traceability }\end{array}$ & $\begin{array}{l}18003, \\
5\end{array}$ & $\begin{array}{l}\text { Recommenda } \\
\text { tions for } \\
\text { correcting } \\
\text { accounting } \\
\text { records }\end{array}$ \\
\hline & $\begin{array}{l}\text { 2) There is no } \\
\text { inventory card } \\
\text { for the fixed } \\
\text { asset with a } \\
\text { reflection of } \\
\text { the initial cost } \\
\text { and an } \\
\text { indication of } \\
\text { the } \\
\text { corresponding } \\
\text { lease } \\
\text { agreement }\end{array}$ & $\begin{array}{l}\text { Accounting } \\
\text { Regulation } \\
6 / 01 \\
\text { «Accounting } \\
\text { for fixed } \\
\text { assets»; } \\
\text { Plan of } \\
\text { accounts for } \\
\text { financial and } \\
\text { economic } \\
\text { activities of } \\
\text { organization } \\
\text { s and } \\
\text { instructions } \\
\text { for its } \\
\text { application }\end{array}$ & $\begin{array}{l}\text { Inventory } \\
\text { card, lease } \\
\text { agreement }\end{array}$ & $\begin{array}{l}\text { Tracking, } \\
\text { arithmetic } \\
\text { control, } \\
\text { inspection }\end{array}$ & - & $\begin{array}{l}\text { Recommenda } \\
\text { tions for } \\
\text { filling out an } \\
\text { inventory } \\
\text { card for a } \\
\text { fixed asset } \\
\text { with a } \\
\text { reflection of } \\
\text { the initial cost } \\
\text { and an } \\
\text { indication of } \\
\text { the } \\
\text { correspondin } \\
\text { g lease } \\
\text { agreement }\end{array}$ \\
\hline
\end{tabular}

\section{Discussion}

Improvement of indicators characterizing financial and economic activity, including efficiency of fixed assets use, is possible as a result of rational use of fixed assets, timely replacement of obsolete equipment, increase of productivity of mechanisms and machines.

Internal and external stakeholders impose high requirements for accounting information characterizing the availability, movement and safety of fixed assets.

In the process of using fixed assets in the production of products, works and services, risks may arise, which are associated with events that are undesirable and negative for the enterprise. The following types of risks are distinguished: technical, production, commercial, innovative and environmental. Under the technical risk there is a probability of losses associated with failures and breakdowns in the operation of fixed assets.

At the production risk there is a probability of losses associated with the implementation of production activities. This type of risk is influenced by quality characteristics of manufactured products, increase in labor productivity, degree of depreciation of fixed assets. Commercial risk is the probability of losses related to the sale of products, performance of work and rendering of services. Innovation risk is associated with the possibility of losses associated with the investment of additional funds in the production of new types of products, works and services. Since the creation of new types of products is associated with the use of highly productive means of production, so there is a risk of acquiring fixed assets that do not meet modern requirements. At the industrial risk there is a probability of decrease of efficiency of functioning of fixed assets. An effective tool for reducing industrial risk is the implementation of measures to prevent accidents.

With environmental risk the probability of the release of harmful substances into the environment in the course of production activities. With the sectoral risk, there is a likelihood of market changes in the commodity markets and finished product markets. For instance, fixed assets are used to deliver procured raw materials, which is a risk factor related to untimely and irregular deliveries. In addition, irrational use of fixed assets in 
places of storage of material values can reduce indicators of their workload and efficiency of their use. Numerous factors connected with competitiveness of an enterprise, impact of business environment, actions of counteragents have an impact on occurrence of business risks. To evaluate the risks associated with the acquisition and use of fixed assets, the following internal control working document can be used (Table 9).

Table 9. ICWD «Test of risks assessment related to fixed assets acquisition and use».

\begin{tabular}{|l|l|l|l|l|}
\hline \multicolumn{1}{|c|}{ Questions } & \multicolumn{2}{|c|}{ Answer options } & \multicolumn{1}{|c|}{ Notes } \\
\cline { 2 - 4 } & Yes & No & partially & \\
\hline $\begin{array}{l}\text { 1. Was there a change in the } \\
\text { technology used to produce the } \\
\text { product? }\end{array}$ & & + & & $\begin{array}{l}\text { Production technology has } \\
\text { not changed }\end{array}$ \\
\hline $\begin{array}{l}\text { 2. Has there been a change in } \\
\text { activities? }\end{array}$ & & + & & $\begin{array}{l}\text { Types of activities did not } \\
\text { change }\end{array}$ \\
\hline $\begin{array}{l}\text { 3. Are there any unscheduled } \\
\text { stoppages of the production } \\
\text { process due to technical } \\
\text { reasons? }\end{array}$ & + & & & $\begin{array}{l}\text { There were unscheduled } \\
\text { stoppages of the production } \\
\text { process for technical reasons }\end{array}$ \\
\hline $\begin{array}{l}\text { 4. Are the personnel being } \\
\text { upgraded to work with new } \\
\text { modern equipment? }\end{array}$ & & & + & $\begin{array}{l}\text { Not all employees upgraded } \\
\text { their skills to work on new } \\
\text { modern equipment }\end{array}$ \\
\hline $\begin{array}{l}\text { 5. Reconstruction and } \\
\text { modernization of fixed assets } \\
\text { are carried out? }\end{array}$ & & + & & $\begin{array}{l}\text { The company does not carry } \\
\text { out reconstruction and } \\
\text { modernization of fixed assets }\end{array}$ \\
\hline $\begin{array}{l}\text { 6. Are repairs and technical } \\
\text { inspections of fixed assets } \\
\text { carried out? }\end{array}$ & & & + & $\begin{array}{l}\text { The terms of repair work and } \\
\text { technical inspections of fixed } \\
\text { assets are not observed }\end{array}$ \\
\hline $\begin{array}{l}\text { 7. Do the objects of fixed assets } \\
\text { used in production activities } \\
\text { comply with environmental } \\
\text { safety requirements? }\end{array}$ & & + & $\begin{array}{l}\text { In production activities, } \\
\text { objects of fixed assets that do } \\
\text { not meet the requirements of } \\
\text { environmental safety are } \\
\text { used }\end{array}$ \\
\hline $\begin{array}{l}\text { 8. Does the specialization of } \\
\text { the enterprise take into account } \\
\text { in determining the structure of } \\
\text { fixed assets? }\end{array}$ & + & & $\begin{array}{l}\text { In determining the structure } \\
\text { of fixed assets takes into } \\
\text { account the specialization of } \\
\text { the enterprise }\end{array}$ \\
\hline $\begin{array}{l}\text { 9. Are the planned indicators of } \\
\text { productivity of fixed assets } \\
\text { achieved? }\end{array}$ & + & & $\begin{array}{l}\text { The planned indicators of } \\
\text { productivity of fixed assets } \\
\text { are achieved }\end{array}$ \\
\hline $\begin{array}{l}\text { 10. Is the impact of scientific } \\
\text { and technological progress on } \\
\text { the formation and acquisition } \\
\text { of fixed assets taken into } \\
\text { account? }\end{array}$ & + & & $\begin{array}{l}\text { Objects of fixed assets are } \\
\text { purchased taking into } \\
\text { account modern requirements } \\
\text { for the production process }\end{array}$ \\
\hline
\end{tabular}

Based on the proposed working paper, you can assess the degree of risk of economic losses from the use of fixed assets and determine the likelihood of technical, financial, economic and environmental risks.

\section{Conclusions}

Thus, the article considers topical issues of internal control of operations with fixed assets, as the most effective tool of enterprise management system.

For improvement of theoretical bases of internal control the conceptual model which represents the logically interconnected system including the basic elements of internal 
control, such as the purpose, problems, functions, object, subject, tools, sources of information, normative base, evidence collection, registration of results of inspection and development of recommendations was offered.

For the development of methodological tools of internal control of fixed assets objects working documents were developed. The proposed working documents allow you to plan and implement control procedures, to accumulate evidence that can be used in the formation of a report on the results of the audit and recommendations to improve the financial and economic activities of the company.

As a result of the control measures the information base is formed, which is used to develop and implement strategic effective management decisions.

\section{References}

1. Y.-F. Kuo, Y.-M. Lin, H.-F. Chien, Finance Research Letters 21, 101805 (2020) https://doi.org/10.1016/j.frl.2020.101805

2. A. Klychova, G. Klychova, A. Zakirova, et al, E3S Web of Conferences 110, 02072 (2019) doi.org/10.1051/e3sconf/201911002072

3. N. Dutta, D. Meierrieks, International Review of Economics \& Finance 73, 114-126 (2021) https://doi.org/10.1016/j.iref.2021.01.002

4. T. Eickelkamp, Journal of Cleaner Production 101, 97-108 (2015) https://doi.org/10.1016/j.jclepro.2015.03.075

5. O.-P. Hilmola, Expert Systems with Applications X5, 100027 (2020)https://doi.org/10.1016/j.eswax.2020.100027

6. G. Klychova, A. Zakirova, R. Mannapova, et al, E3S Web of Conferences 110, 02075 (2019) doi.org/10.1051/e3sconf/201911002075

7. A.S. Manikas, P.C. Patel, P. Oghazi, Journal of Business Research 103, 119-129 (2019) https://doi.org/10.1016/j.jbusres.2019.06.014

8. D. Brennan, Principles, Concepts and Applications, 209-242 (2020) https://doi.org/10.1016/B978-0-12-819466-9.00008-0

9. K. Kim, Journal of Corporate Finance 60, $101528 \quad$ (2020) https://doi.org/10.1016/j.jcorpfin.2019.101528

10. G. Klychova, A. Zakirova, E. Sadrieva et al, E3S Web of Conferences 91, 06002 (2019) https://doi.org/10.1051/e3sconf/20199106002

11. M.P. Bauman, Research in Accounting Regulation 25, 149-156 (2013) https://doi.org/10.1016/j.racreg.2013.08.002

12. G. Klychova, A. Zakirova, Sh. Khusainov et al, E3S Web of Conferences 157, 04022 (2020) https://doi.org/10.1051/e3sconf/202015704022

13. M. Roussy, Critical Perspectives on Accounting 24, 550-571 (2013) https://doi.org/10.1016/j.cpa.2013.08.004

14. J. Wang, K. Hooper, Critical Perspectives on Accounting 49, 18-30 (2017) https://doi.org/10.1016/j.cpa.2017.04.003

15. J.L. Gissel, Journal of Accounting Education 37, 61-66 (2016) https://doi.org/10.1016/j.jaccedu.2016.10.001

16. H. Cho, J.R. Chung, Y.J. Kim, Pacific-Basin Finance Journal 10, 101517 (2021) https://doi.org/10.1016/j.pacfin.2021.101517

17. G.S. Klychova, A.R. Zakirova, K.Z. Mukhamedzyanov et al, Journal of Engineering and Applied Sciences 12(19), 4966-4973 (2017) DOI: 10.3923/jeasci.2017.4966.4973 
18. K. Chalmers, D. Hay, H. Khlif, Journal of Accounting Literature 42, 80-103 (2019) https://doi.org/10.1016/j.acclit.2018.03.002

19. A. Zakirova, G. Klychova, R. Nurieva et al, Advances in Intelligent Systems and Computing 1259 AISC, 98-123 (2021) https://doi.org/10.1007/978-3-030-57453-6_10

20. E. Demirakos, The International Journal of Accounting 53, 253-254 (2018) https://doi.org/10.1016/j.intacc.2018.07.001

21. A. Zakirova, G. Klychova, K. Mukhamedzyanov et al, Advances in Intel-ligent Systems and Computing 1258 AISC, 687-707 (2021) https://doi.org/10.1007/978-3030-57450-5_59

22. Y.-T. Chang, H. Chen, R.K. Cheng, W. Chi, Journal of Contemporary Accounting \& Economics 15, 1-19 (2019) https://doi.org/10.1016/j.jcae.2018.11.002

23. W. Shu, Y. Chen, B. Lin, Y. Chen, China Journal of Accounting Research 11, 407-427 (2018) https://doi.org/10.1016/j.cjar.2018.09.002

24. X.-d. Ji, W. Lu, W. Qu, Journal of Contemporary Accounting \& Economics 14, 266287 (2018) https://doi.org/10.1016/j.jcae.2018.07.002

25. D.B. Bryan, Advances in Accounting 36, 11-26 (2017) https://doi.org/10.1016/j.adiac.2016.09.005

26. Kh. Kelly, H.-T. Tan, Accounting, Organizations and Society 56, 1-20 (2017) https://doi.org/10.1016/j.aos.2016.12.002

27. M. Hanskamp-Sebregts, P.B. Robben, H. Wollersheim, M. Zegers, Health Policy 124, 216-223 (2020) https://doi.org/10.1016/j.healthpol.2019.11.013

28. W. Rodgers, S.A. Fayi, Accounting Forum $21 \quad$ (2018) https://doi.org/10.1016/j.accfor.2018.12.001

29. M. Eulerich, J. Kremin, D.A. Wood, Advances in Accounting 45, 100410 (2019) https://doi.org/10.1016/j.adiac.2019.01.001

30. A. Briozzo, D. Albanese, Journal of International Accounting, Auditing and Taxation 38, 100302 (2020) https://doi.org/10.1016/j.intaccaudtax.2020.100302

31. D. Vakhitov, A. Zamaletdinov, Procedia Economics and Finance 23, 839-845 (2015) doi.org/10.1016/S2212-5671(15)00365-2

32. G. Klychova, A. Zakirova, A. Dyatlova, et al, E3S Web of Conferences 164, 10010 (2020) https://doi.org/10.1051/e3sconf/202016410010 